\title{
VODNÍK (z pohledu lékaře)
}

Jihočeská univerzita v Českých Budějovicích, Zdravotně sociální fakulta

Vodník patří $\mathrm{k}$ našim známým pohádkovým bytostem. Je menší ohnuté postavy, třebaže s rysy stárnoucího muže. Má modrofialovou plet' s výrazným nazelenalým nádechem, nápadně kulaté oči obkroužené žlutozeleným bělmem vystupují z šikmo postavených víček. Hlava je kryta žlutými vlasy. Kulaté dlaně s krátkými prsty spojenými plovací blánou končí paličkovitě rozšírenými konečky posledních článků, které jsou překryty modravými až fialovými nehty klenutými do tvaru hodinových sklíček. Sedá na bobku a rád prozpěvuje rytmické melodie. Naše výtvarná tradice jej barevně obléká do zeleného kabátku s prodlouženými šosy, červené vesty a červených botek. Sám si svůj oděv šije, sešívá lýkem a metlicí, rákosím. Klobouček s kohoutím perem a pestré fábory na kloboučku dokládají snahu o zalíbení a o získání sympatií lidí (obr. 1). Inspirace umělců - básníků a malírů - je založena na príhodách přenášených lidovým vyprávěním z generace na generaci ve slovanských krajích Čech, Polska a Ukrajiny. Vyprávěním nabývá démonologických prvků, jako jsou život pod vodou, neobyčejná moc a síla daná spojením s vodou, změny podoby. Vedle toho se však ve vyprávění objevuje řada dějových prvků, které odpovídají reálným jevům venkovského života kolem vody. Tak jako vytvářejí jednotlivé popisné a dějové prvky reálný dojem, je možný i jejich reálný základ. I pro popisovanou postavu může existovat podklad vycházející ze života. Může být odpozorován, vyprávěn a převyprávěn, vyprávěním doplňován, vlastní úvahou a nedokonalou vzpomínkou dokreslen, zveličován, zobecněn. Je nějaký podobný podklad pro vodníkovu postavu? Existovala nějaká postava, situace, která se lidovou tradicí dostala z podvědomí obav lidí do básnického zpracování a literárního rozšíření? Pokusili jsme se ozřejmit, co by na vodníkově postavě mohlo být medicínsky pravděpodobné a tudíž i vysvětlitelné.

Namodralá plet' je známkou cyanózy - nedostatečného okysličování tkání krví, která obsahuje nízký objem kyslíku. Jednou z příčin hypoxémie je omezené množství krve, která se plicním oběhem dostává k plicním sklípkům, kde hemoglobin červených krvinek váže kyslík z vdechnutého vzduchu. Taková situace vzniká naprŕklad při vrozené překážce $\mathrm{v}$ odtoku krve $\mathrm{z}$ pravé srdeční komory do plicní tepny - neprůchodnosti nebo zúžení plicnice. Je součástí vrozené srdeční vady, známé pod tradičním názvem Fallotova tetralogie. Přetrvávající otvor mezi oběma komorami umožňuje neokysličené krvi vracející se $z$ těla odtékat znovu do aorty a ke tkáním tělesných orgánů, aniž by se obohatila kyslíkem v plicích. Nedokonalé okysličení tkání - včetně kůže - dalo takovým dětem hromadné pojmenování - modré děti.

Nedostatek kyslíku v krvi podporuje tvorbu většího množství červených krvinek. Velké množství proudící krve - plethora - zdůrazňuje zarudnutí průsvitných spojivek $\mathrm{v}$ očních důlcích, zdůrazňuje nápadné zbarvení rtů a ušních lalůčků a koneckonců i pleti na obličeji a na kůži celého těla anebo pod nehty. Nedostatečně okysličené konečky prstů se rozšiřují ve tvaru paliček. Od cyanotického obličeje se nápadně odráží žlutavé zbarvení vlasů s nízkým obsahem barviva. Nedostatečná dodávka kyslíku tkáním vede k únavnosti takového jedince, omezuje jeho celkovou aktivitu. Dítě začíná později chodit, málo se pohybuje, zadýchává se, posedává a vyhledává úlevnou polohu ve dřepu. Poměrně často jsou postiženy vývojovou anomálií i jiné orgány - relativně časté je spojení s atrézií žlučových cest a s Downovou chorobou - a projevy vad vedou k dalšímu zvýraznění zevních projevů. Vrozená neprůchodnost žlučových cest postupně vede $\mathrm{k}$ přestupu rozloženého žlučového barviva do krevního oběhu. Vzniklá žloutenka má charakteristický nádech do tmavozelena. Část cyanotických dětí - $12 \%$ s fallotovskou vadou má postiženy i jiné orgány.

Uvedené znaky tvoří podklad pro uvažovanou možnost, že pravděpodobným předobrazem fenotypu vodníka je jedinec s Fallotovou tetralogií (obr. 2-4) a případně s atrézií žlučových cest (tab. 1), s Downovou chorobou (trisomii 21) anebo i s dalšími vrozenými anomáliemi postihujícími kupř́kladu skelet páteře (obr. 5), např́klad Klippelův - Feilův syndrom (tab. 2).

Vada vzniká chybným vývojem srdeční trubice v průběhu 4. až 6. týdne embryonálního života. $\mathrm{V}$ té době si matka ani nemusí být vědoma těhotenství a jakákoli noxa může plod poškodit. Jde nejen o běžná chřipková či jiná virová onemocnění, ale i o toxické poškození z prostředí, včetně toxických látek jako alkohol. Ale může jít i o poškození úmyslné, např́klad se snahou o potrat, at' již mechanickým prostředkem či nějakou látkou 
užívanou v lidovém léčitelství. Poškozené novorozeně může přežít. Závisí to na závažnosti vady a jejích funkčních projevech. Nejvíce se mění dítě v průběhu šestinedělí. Patologické změny vyvolané vrozenými malformacemi se právě $\mathrm{v}$ tomto období nejvýrazněji projevují. Podle lidové pověry nesmí šestinedělka opustit ani na okamžik své novorozeně, nebot' temné síly by jej mohly vyměnit - za vodníka.

$\mathrm{V}$ ojedinělých prrípadech se takový jedinec může dožít dospělého věku. Vodník $\mathrm{v}$ mnoha ohledech jedná jako lidská postava. Zájem o dívky a jejich vábení dárky $\mathrm{v}$ podobě mašlí veselých barev jej dělá lidským. Lze jej prrirovnat $\mathrm{k}$ zájmu obvyklému u sexuálně heterogenně cítícího muže. Zamilovaný vodník v Jiráskově Lucerně trpí láskou k Haničce stejně bolestně jako jiní čeští chasníci. Voskovcova a Werichova postava Čochtana v jejich dramaturgické úpravě muzikálu Divotvorný hrnec nebo Urbanův hastrman jsou postavami s výrazně lidskými rysy chování. Vodník má i svou tragickou tvár. Topí lidi, zvláště děti. Čelakovského znárodnělá píseň „Za poledne rychlý klouček po hrázi si poskakoval“ líćí, jak jej vodník zlákal do vody a připravil o život. Vodník nesnáší posměch, se svou pomstou dokáže čekat. Ve známé Erbenově baladě neváhá pomstít svou urážku po odchodu ženy usmrcením jejich dítěte. Ve Svátko- vě zkazce od Blatné urážku těhotnou ženou pomstí červenou skvrnou $\mathrm{v}$ barvě své vesty na prsou novorozence, která přetrvá po celý jeho další život až do jeho smrti - jak jinak - utopením. Podobně Urbanův historizující schematický román se nevyhýbá pomstě pomyslné urážky a s tím spojeného boje o nevěstu.

A jak došlo ke spojení s vodou? Lze se domnívat, že přes mlýn.

$\mathrm{V}$ průběhu dob byly vodní mlýny $\mathrm{v}$ hlubokých údolích řek svobodným povoláním, chráněným a uznávaným. Mezi čeládkou nechyběla děvečka. Lze si představit, že nežádoucí těhotenství svobodné dívky na mlýnské samotě - mohlo jít i o následek incestu - bylo následováno pokusem o vypuzení plodu, např́klad lektvary a odvary dostupného koření. Narodilo-li se poškozené dítě s cyanotickou a nazelenalou kůží, paličkami na konci prstů, bylo snadnějši príčíst takovou bytost nepřirozeným silám než přiznat se $\mathrm{k}$ rodičovství. A stačilo pár cestujících tovaryšů, kteří příběh o podobném tvoru vyprávěli $\mathrm{v}$ dalších mlýnicích, a zpráva o vodníkovi - i s odpovídajícím popisem - se roznesla. Vyprávěčům stačila jedna taková postava - a v průběhu třicetileté války např́klad se pohybem lidí zpráva dostala široko daleko.

\section{TEXT K ILUSTRACÍM}

Obr. 1: Obrazové ztvárnění vodníka podle českých pohádek (autor Ondřej Tůma).

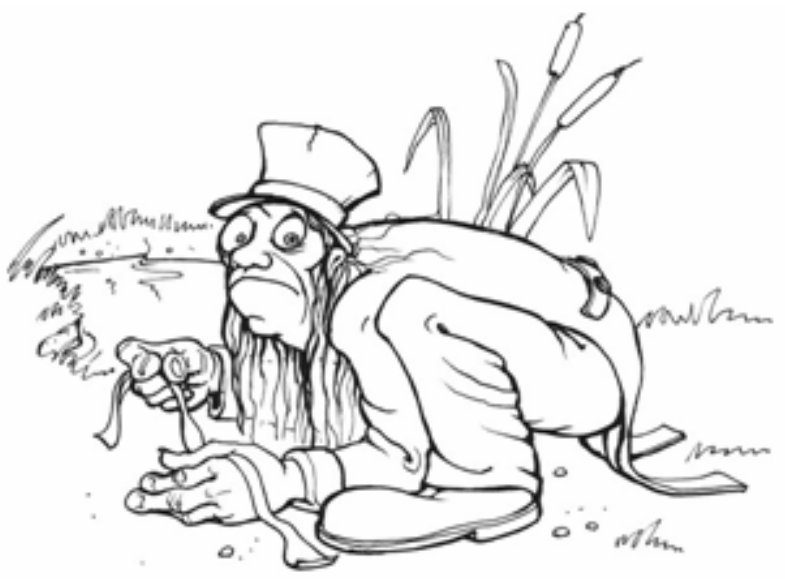


Obr. 2: Přehledný skiagram srdce a plic u dítěte s Fallotovou tetralogií. Chudá plicní cévní kresba je ukazatelem sníženého průtoku krve plicním cévním řečištěm způsobeným obstrukcí ve výtokovém traktu pravé komory. Srdeční stín má naznačen dřevákovitý tvar s nadzvednutým a otupeným srdečním hrotem tvořeným hypertrofickou pravou komorou

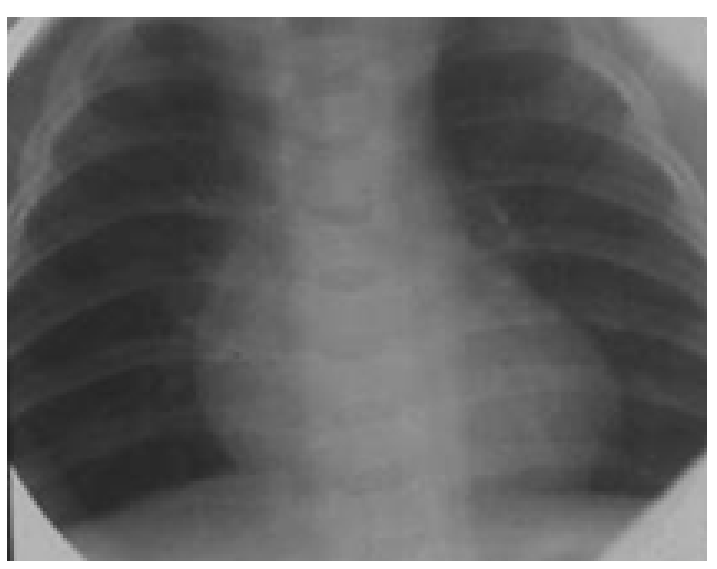

Obr. 3: Obraz srdečních dutin pomocí jevu magnetické resonance v T1w obrazu „černé krve“ u Fallotovy tetralogie v koronální rovině. Hypoplastický průsvit zúženého kmene plicnice kontrastuje se širokým kořenem aorty nasedajícím na defekt komorového septa ve výtokovém traktu pravé komory

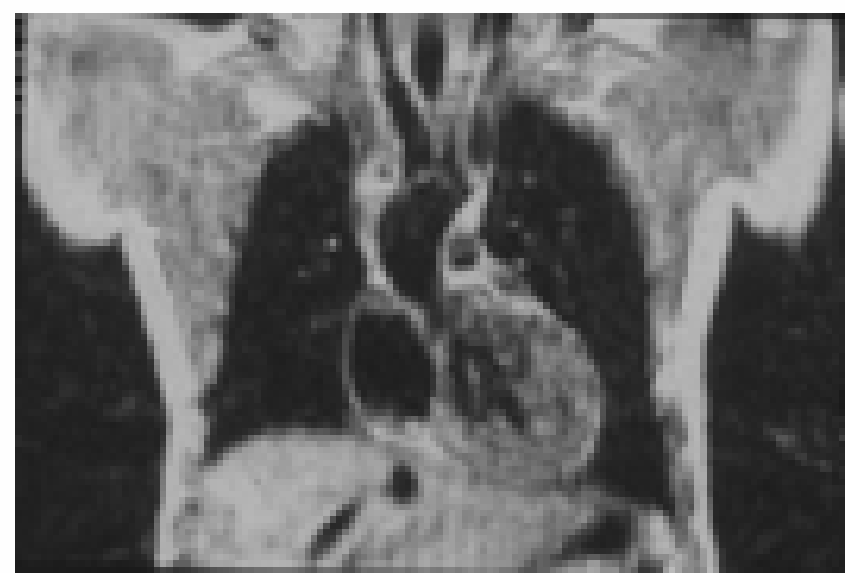


Obr. 4: Selektivní angiokardiografie se vstřikem kontrastní látky do pravé komory - frontální projekce. Stenotický výtokový trakt pravé komory. Současně s plicnicí se z pravé komory plní i široký kořen aorty, který nasedá na defekt komorového septa.

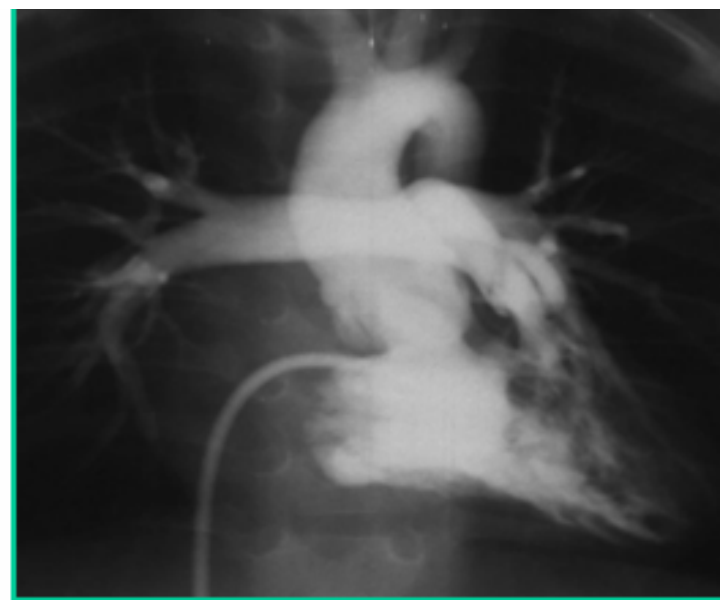

Obr. 5: Přehledný snímek srdce a plic u novorozence s VACTERL syndromem - mnohočetnými vrozenými malformacemi, které postihují několik orgánů. Snímek je obrazem ageneze levého plicního křídla s laevopozicí srdce a mediastina. Skolióza páteře je výsledkem četných anomálií obratlových těl a žeber. Atrézie jícnu není spojena s dolní broncho-ezofageální píštělí, proto je perkutánně do žaludku zaveden katetr.

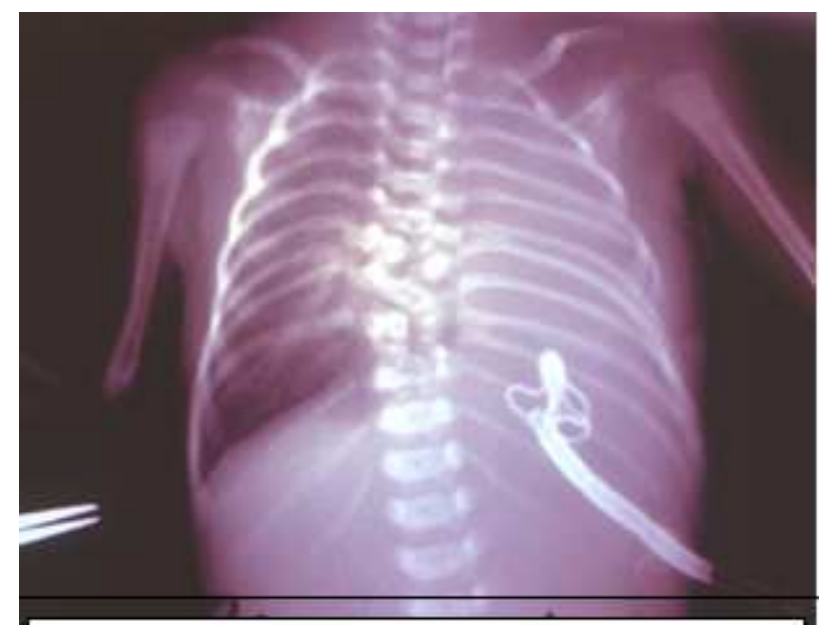


Tab. 1: Výskyt spojených malformací srdce, trávicí trubice a hepatobiliárního traktu

Extrahepatická atrézie žlučových cest u dětí je spojena s:

- dalšími malformacemi

$$
\begin{array}{lrl}
\text { v } & 8,4 \% & \text { (Kataria) } \\
\text { v } 55,5 \% & \\
\text { v } & 66,6 \% & \text { (Kataria) } \\
\text { v } & 2,0 \% & \text { (Czeizel) }
\end{array}
$$$$
\text { s anomáliemi trávicí trubice }
$$

- defektem komorového septa

Tab. 2: Vrozené anomálie př̀i Klippelově - Feilově malformaci

Klippelův - Feilův syndrom se Sprengelovou deformitou přichází sporadicky, zhruba jednou na 42 tisíc narozených. Je charakterizován krátkým krkem s nízko uloženou hranicí vlasů anebo jako kongenitální synostóza krčních obratlů s jednostrannou deformitou krční páteře. Existuje mnoho variací s dalšími anomáliemi:

- Sprengelova deformita (20-25\%) s omovertebrálním spojením vysoko uložené lopatky s krční páteří. Jde o poruchu prenatálního sestupu lopatky z cervikální do obvyklé thorakální polohy ve 2.-3. měsíci těhotenství. V 90 \% jde o jednostrannou deformitu. Hypoplastická lopatka je uložená vysoko v krční oblasti a omezuje abdukci. Přibližně u čtvrtiny př́padů je lopatka kostěnně, chrupavčitě či vazivově spojena s páteř́ jako os omovertebrale.

- Krční žebra (10-15\%).

- Pterygium colli.

- Spina bifida.

- Deformovaná žebra, rozštěp patra, asymetrie lebky, deformace dentu, otevřené foramen ovale v srdci, defekt komorového septa, anomálie ledviny a střevní duplikatury.

Stanislav Tỉma stuma@zsf.jcu.cz 